\title{
Identification of a Satellite Fatty Acid Ethyl Ester Synthase from Human Myocardium as a Glutathione S-Transferase
}

\author{
Puran S. Bora, Curtis A. Spilburg, and Louis G. Lange \\ Cardiology Division, Department of Medicine, Jewish Hospital of St. Louis at the \\ Washington University Medical Center, St. Louis, Missouri 63110
}

\begin{abstract}
Nonoxidative alcohol metabolism catalyzed by fatty acid ethyl ester (FAEE) synthases may contribute to extrahepatic injury resulting from alcohol abuse. Unlike rabbit myocardial FAEE synthase, that from human heart has a satellite minor synthase (I) eluting from DEAE cellulose at a conductivity of 5 mS. Synthase I was purified 1,118-fold to homogeneity by sequential gel permeation, hydrophobic interaction, and $\mathrm{Su}$ perose-12 fast-protein liquid chromatographies. SDS-PAGE showed a single polypeptide with a molecular mass of $26 \mathbf{~ k D}$ and gel permeation chromatography indicated a molecular mass of $52 \mathrm{kD}$ for the active enzyme. Homogeneous synthase I catalyzed ethyl ester synthesis at highest rates with unsaturated octadecanoic fatty acid substrates. The amino acid composition of synthase I was highly homologous to that of human myocardial major synthase, recently identified as an acidic glutathione (GSH) S-transferase. Antibody raised against homogeneous human heart major synthase cross-reacted with the 26-kD synthase I. FAEE synthase co-chromatographed with GSH S-transferase on DEAE cellulose, Sephadex G-100 and S-hexylglutathione agarose, and also displayed GSH S-transferase activity in catalyzing the conjugation of GSH with nitrobenzene-containing carcinogens. Thus, human myocardium contains a satellite peak of FAEE synthase activity and it is a neutral GSH S-transferase.
\end{abstract}

\section{Introduction}

The World Health Organization concluded in 1964 that an important association existed between excessive drinking of alcohol and development of tumors of the pharynx, esophagus, stomach, and liver (1). Moreover, chronic ethanol ingestion has a carcinogenic enhancing effect for tumors of various tissues induced by polycyclic hydrocarbons and nitrosamines $(2,3)$. Our laboratory has recently established a biochemical link between alcohol and carcinogen metabolism by reporting a high degree of homology between the major fatty acid ethyl ester (FAEE) ${ }^{1}$ synthase from human myocardium and the glu-

Address reprint requests to Dr. Lange, Cardiology Research, Yalem 305, Jewish Hospital of St. Louis, 216 S. Kingshighway, St. Louis, MO 63110. 1989.

Received for publication 23 May 1989 and in revised form 20 July

1. Abbreviations used in this paper: BME, 2-mercaptoethanol; FAEE, fatty acid ethyl ester; GST, glutathione S-transferase.

J. Clin. Invest.

(c) The American Society for Clinical Investigation, Inc.

0021-9738/89/12/1942/05 \$2.00

Volume 84, December 1989, 1942-1946 tathione (GSH) S-transferases, or GSTs, enzymes that detoxify a wide variety of polycyclic carcinogens and xenobiotics (4).

FAEEs were recently identified in heart and these neutral lipids were shown to accumulate in vivo after being synthesized in the myocardium (5-8). In isolated rabbit heart mitochondria, these ethyl esters induce mitochondrial dysfunction in vitro (5), a finding that establishes a link between alcohol intake and mitochondrial damage, a hallmark of alcohol-induced heart muscle diseases.

FAEE synthase exists as two forms in rabbit myocardium and both of these enzymes catalyze the synthesis of FAEEs (9). These two forms can be separated from each other by chromatography on DEAE cellulose (9). However, after chromatography on DEAE cellulose, we have now identified three forms of synthase in human myocardium. The heretofore undescribed first form eluting at $5 \mathrm{mS}$ on DEAE-cellulose chromatography (synthase I) has not been isolated and purified from any species.

In the present investigation, we report the isolation, purification to homogeneity, and characterization of synthase I from human myocardium. In addition, we also demonstrate a relationship between synthase I and GST, an acidic isozyme which has recently been described to be the major FAEE synthase (4). The present data establish a second structural and functional link between alcohol and carcinogen/xenobiotic metabolism and thus provide a molecular framework for further evaluating the long-accepted clinical association between alcohol abuse and oncogenesis.

\section{Methods}

Materials. Ethyl $\left[{ }^{3} \mathrm{H}\right]$ oleate was synthesized in $70 \%$ yield by the acidcatalyzed esterification of $\left[{ }^{3} \mathrm{H}\right]$ oleic acid in ethanol $(9) .\left[{ }^{14} \mathrm{C}\right]$ Oleic acid $(59.9 \mathrm{Ci} / \mathrm{mol})$ and $\left[{ }^{3} \mathrm{H}\right]$ oleic acid $(5.7 \mathrm{Ci} / \mathrm{mol})$ were purchased from Amersham Corp, Arlington Heights, IL. S-hexylglutathione agarose was obtained from Sigma Chemical Co., St. Louis, MO; 1-chloro-2,4dinitrobenzene, 1-chloro-4-nitrobenzene, and 1,2-dichloro-4-nitrobenzene were purchased from Aldrich Chemical Co., Milwaukee, WI. All other reagents were the highest commercially available grade.

Homogenate preparation. Ventricular myocardium $(60 \mathrm{~g})$ from human heart was placed in ice-cold $1 \mathrm{mM}$ 2-mercaptoethanol (BME) $10 \mathrm{mM}$ Tris, $\mathrm{pH} 8.0$, and all subsequent procedures were performed at $4^{\circ} \mathrm{C}$. The myocardium was minced and homogenized for $60 \mathrm{sin} 10 \mathrm{vol}$ of cold $1 \mathrm{mM}$ BME, $10 \mathrm{mM}$ Tris, pH 8.0, with a homogenizer (Polytron PT-20, Brinkmann Instruments Co., Westbury, NY) at half-maximal setting. Homogenate was first centrifuged at $14,000 \mathrm{~g}$ for $30 \mathrm{~min}$ and the resulting supernatant was again centrifuged at $48,400 \mathrm{~g}$ for $1 \mathrm{~h}$. Floating fats were removed by aspiration after each centrifugation. The supernatant was dialyzed overnight against $1 \mathrm{mM}$ BME, $10 \mathrm{mM}$ Tris, pH 8.0, before chromatography. Protein was estimated by the method of Bradford (10) with $\gamma$-globulin as standard.

Enzyme assay. FAEE synthase activity was determined according to the method of Mogelson and Lange (9) and Bora et al. (4). GST activity was measured spectrophotometrically at $340 \mathrm{nM}$ using 
$1 \mathrm{mM}$ 1-chloro-2,4-dinitrobenzene and $1 \mathrm{mM}$ reduced GSH as substrates (11).

Electrophoresis. SDS-PAGE (12) was used to determine the molecular weight and the purity of the enzyme. Gels containing $4.5 \%$ (stacking gel, $\mathrm{pH} 6.8$ ) and $12.5 \%$ (separating gel, $\mathrm{pH} \mathrm{8.8)} \mathrm{acrylamide} \mathrm{were} \mathrm{run}$ at $150 \mathrm{~V}$ (stacking) and $200 \mathrm{~V}$ (separating), after which they were fixed and stained with silver (13) or with $0.2 \%$ Coomassie brilliant blue Enzyme subunit molecular weight was calculated using polypeptide standards of known molecular weight (phosphorylase b [94,000]; bovine serum albumin [66,000]; ovalbumin [43,000]; carbonic anhydrase $[29,000]$; soybean trypsin inhibitor $[20,000]$, and $\alpha$-lactalbumin $[14,000])$.

Amino acid analysis. An automated amino acid analyzer (model 6300 , Beckman Instruments, Inc., Fullerton, CA) was used for amino acid analysis. Hydrolysis was performed in vacuo using $6 \mathrm{~N} \mathrm{HCl}$ in a sealed vessel at $110^{\circ} \mathrm{C}$ for $24 \mathrm{~h}$. Cysteine and methionine were quantitated after oxidation with performic acid prior to hydrolysis.

Immunoblot analysis. Purified synthases were subjected to gel electrophoresis on the Phast System (Pharmacia Fine Chemicals, Piscataway, NJ) and then electrophoretically transferred to a nitrocellulose sheet $(14,15)$. After transfer, the nitrocellulose sheet was washed four times with $300 \mathrm{ml}$ of phosphate-buffered saline containing $0.3 \%$ (vol/ vol) Tween 20 and then incubated for $3 \mathrm{~h}$ with rabbit anti-major synthase antibody and $1 \%$ ovalbumin. After washing three times with phosphate-buffered saline, the sheet was incubated with ${ }^{125}$ I-Protein A (150 $\left.\mu 1,10^{5} \mathrm{cpm} / \mathrm{pmol}\right)$ containing $1 \%$ ovalbumin. The nitrocellulose sheet was then washed again with phosphate-buffered saline, dried and exposed to X-ray film for $72 \mathrm{~h}$. Antibody against the major synthase does not cross-react with the minor synthase, albumin, or cholesterol esterase, nor does preimmune serum recognize any of the synthases.

\section{Results}

Fractionation of FAEE synthase forms. When the soluble fraction from a homogenate of human myocardium was fractionated on DEAE cellulose $(2 \times 18 \mathrm{~cm})$ in $1 \mathrm{mM}$ BME, 10 $\mathrm{mM}$ Tris, $\mathrm{pH} \mathrm{8.0,} \mathrm{three} \mathrm{peaks} \mathrm{of} \mathrm{FAEE} \mathrm{synthase} \mathrm{activity} \mathrm{were}$ consistently and reproducibly observed (Fig. 1). These species are designated as follows: synthase $\mathrm{I}$, eluting at $5 \mathrm{mS}$; minor synthase (II) eluting at $7 \mathrm{mS}$; and the major synthase (III) eluting at $11 \mathrm{mS}$. This pattern is unique to human heart since only two activity peaks are observed in other mammals (9). This elution profile is not affected by the presence of protease inhibitors, indicating that this heterogeneity is not due to adventitious proteolysis. Recently the major synthase was puri-

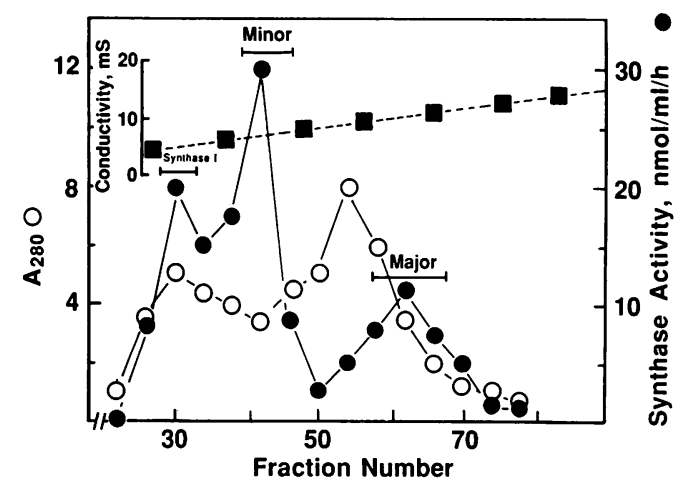

Figure 1. DEAE-cellulose chromatography. Enzyme activity from human myocardium was fractionated in $1 \mathrm{mM}$ BME, $10 \mathrm{mM}$ Tris, $\mathrm{pH}$ 8.0. The column was developed with a linear salt gradient running from buffer to $400 \mathrm{mM} \mathrm{NaCl}(\mathbf{0})$. Fractions (6 ml) were collected at $40 \mathrm{ml} / \mathrm{h}$ and monitored for protein $(0)$ and synthase activity (•).

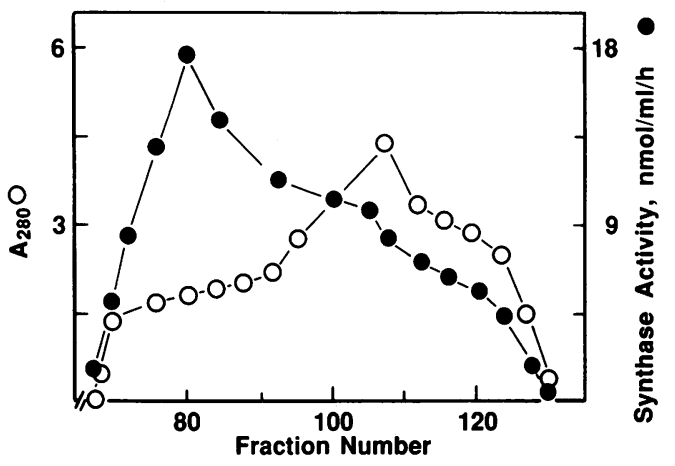

Figure 2. Gel permeation chromatography of FAEE synthase I. Protein was applied at $6 \mathrm{ml} / \mathrm{h}$ to Sephadex G-100 $(2.5 \times 72 \mathrm{~cm})$ equilibrated with $1 \mathrm{mM}$ BME, $10 \mathrm{mM}$ Tris, $50 \mathrm{mM}$ sodium phosphate, $\mathrm{pH}$ 7.0. Fractions $\left(2.5 \mathrm{ml}\right.$ ) were collected and monitored for $A_{280}$ (०) and FAEE synthase activity $(\bullet)$.

fied to homogeneity and was shown to be homologous to GSH transferase (4). However, the properties of synthase I are unknown and its relationship to the minor and major enzymes is also unknown.

Purification of FAEE synthase I. In order to concentrate the FAEE synthase I pool $(45 \mathrm{ml})$ from the DEAE column, solid ammonium sulfate was added to $70 \%$ of saturation. The precipitate was collected by centrifugation, dialyzed against

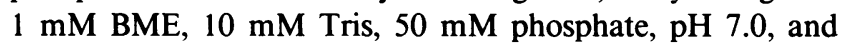
applied to a Sephadex G-100 column $(2.5 \times 72 \mathrm{~cm})$. The enzyme was recovered in $75 \%$ yield as a single, broad peak (Fig. 2). When the major synthase is chromatographed on the same column at the same flow rate, it emerges at a larger elution volume. However, fast-protein liquid chromatography (FPLC) gel filtration and SDS gels (see below) indicate that these two species have the same molecular mass, $52 \mathrm{kD}$. The different G-100 elution volume observed here, as well as the broad activity peak, probably reflects matrix protein interaction, a common phenomenon for lipid enzymes.

An octyl Sepharose column $(1 \times 7 \mathrm{~cm})$ was equilibrated with $1 \mathrm{mM}$ BME, $10 \mathrm{mM}$ Tris, $50 \mathrm{mM}$ phosphate, $\mathrm{pH} 7.0$, and those Sephadex G-100 fractions with activity $>8 \mathrm{nmol} / \mathrm{ml}$ per $\mathrm{h}$ were applied at $20 \mathrm{ml} / \mathrm{h}$. After washing the resin with $0.10 \%$ sodium cholate in the same buffer, the column was developed further with a linear cholate gradient running from $0.10 \%$ to $0.20 \%$ and the enzyme emerged at $0.13 \%$ cholate in $70 \%$ yield (data not shown).

Fractions containing enzyme activity greater than $2 \mathrm{nmol} /$ $\mathrm{ml}$ per $\mathrm{h}$ were pooled and applied to Superose-12 FPLC, equilibrated with $1 \mathrm{mM}$ BME, $10 \mathrm{mM}$ Tris, $50 \mathrm{mM}$ sodium phosphate, $\mathrm{pH}$ 7.0. Enzymatic activity emerged at an elution volume corresponding to a molecular mass of $52 \mathrm{kD}$ (Fig. 3). SDS-PAGE of this material $(35 \mu \mathrm{g})$ showed a single band of molecular mass of $26 \mathrm{kD}$ (Fig. 4) when stained either with silver or Coomassie blue. The enzyme therefore is a dimer, consisting of two 26-kD subunits. Synthase I showed significant cross-reactivity to antibody raised against homogeneous human heart major FAEE synthase, both by solid-phase radioimmunoassay and immunoblot (data not shown).

The purification summary of the FAEE synthase $I$ is given in Table I. An overall yield of $9 \%$ was obtained for the 1,118 fold purified enzyme when assayed in the presence of $0.2 \mathrm{M}$ ethanol and $0.91 \mathrm{mM}$ oleic acid. Myocardium contains $\sim 20$ $\mu \mathrm{g}$ of the FAEE synthase I per $\mathrm{g}$ of tissue. 


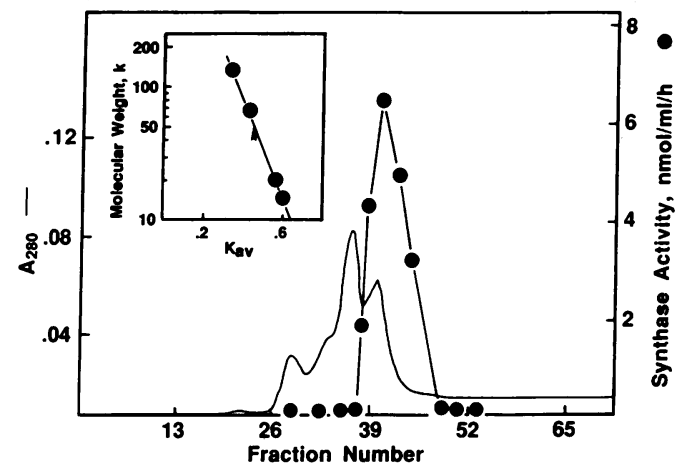

Figure 3. Superose-12 FPLC. Protein was applied at $0.3 \mathrm{ml} / \mathrm{min}$ to a Superose-12 column equilibrated with $1 \mathrm{mM}$ BME, $10 \mathrm{mM}$ Tris, 50 $\mathrm{mM}$ sodium phosphate, $\mathrm{pH} 7.0$, and the protein was eluted with the same buffer. Fractions $(0.3 \mathrm{ml})$ were monitored for $A_{280}(-)$ and FAEE synthase activity (๑). Molecular weight standard given in thousands (k).

Amino acid analysis. Based on a subunit molecular mass of $26 \mathrm{kD}$, the amino acid composition of the synthase $I$ is very similar to that reported for the major synthase from human heart (Table II), another dimeric enzyme with a subunit molecular mass of $26 \mathrm{kD}$ and recently described as a member of the GST family (4).

Kinetic properties. The substrate specificity of the FAEE synthase I was examined by measuring the rate of ethyl ester synthesis in the presence of fatty acids of different chain length and degree of saturation (Table III). The following ${ }^{14} \mathrm{C}$-labeled fatty acids were used: palmitate, stearate, oleate, linoleate, and arachidonate. In all cases, linear Lineweaver-Burke plots were found and the maximum rates of synthesis $\left(V_{\max }\right)$ were observed with linoleate and oleate, 222 and $200 \mathrm{nmol} / \mathrm{mg}$ per h, respectively. Saturated fatty acids had the lowest rates of ethyl ester synthesis, with rates of 36 and $32 \mathrm{nmol} / \mathrm{mg}$ per $\mathrm{h}$ for stearate and palmitate, respectively. In contrast, binding affinities $\left(K_{\mathrm{m}}\right)$ for these fatty acid substrates were all nearly the same, $0.40-0.59 \mathrm{mM}$ at a fixed oleate concentration of 0.91 $\mathrm{mM}$, the $V_{\max }$ and $K_{\mathrm{m}}$ for ethanol were $59 \mathrm{nmol} / \mathrm{mg}$ per $\mathrm{h}$ and $0.30 \mathrm{M}$, respectively. Importantly, the homogeneous synthase I was also active as a GSH transferase with the standard substrate 1-chloro-2,4-dinitrobenzene $(1 \mathrm{mM})$ as substrate $(8$ $\mathrm{mol} / \mathrm{min}$ per mol enzyme), as well as with the carcinogens 1-chloro-4-nitrobenzene $(4.75 \mathrm{~mol} / \mathrm{min}$ per mol enzyme $)$ and 1,2-dicholoro-4-nitrobenzene $(5.93 \mathrm{~mol} / \mathrm{min}$ per $\mathrm{mol}$ enzyme).

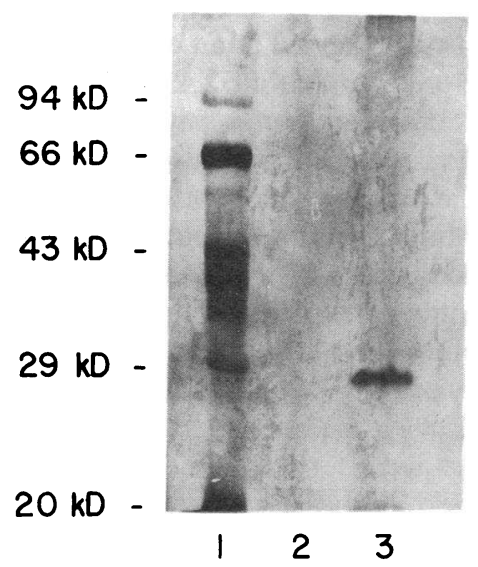

Figure 4. SDS-PAGE of FAEE synthase I purification. Lane 1, molecular mass standards; lane 2, blank; lane 3, Superose-12. This gel was stained with silver; similar results were noted after Coomassie brilliant blue staining.
Table I. Purification of FAEE Synthase I

\begin{tabular}{lcrcrc}
\hline \multicolumn{1}{c}{ Step } & $\begin{array}{c}\text { Total } \\
\text { protein }\end{array}$ & $\begin{array}{c}\text { Total } \\
\text { activity }\end{array}$ & $\begin{array}{c}\text { Specific } \\
\text { activity }\end{array}$ & Purification & Yield \\
\hline & $m g$ & $n m o l / h$ & $n m o l / m g$ per $h$ & -fold & $\%$ \\
Cytosol* $^{*}$ & 5,950 & 2,040 & 0.34 & 1 & 100 \\
DEAE-cellulose $^{2}$ & 114 & 787 & 6.9 & 20 & 39 \\
G-100 & 27 & 468 & 17.3 & 51 & 23 \\
Octyl-Sepharose & 3.0 & 204 & 68.0 & 200 & 10 \\
Superose-12 & 0.50 & 190 & 380.0 & 1,118 & 9
\end{tabular}

* Synthase I activity in the cytosol was calculated from the proportions of synthase I, major and minor activities, as determined after DEAE-cellulose chromatography.

Co-chromatography. Several chromatography experiments were performed to confirm that synthase $I$ is a GST. First, the DEAE-cellulose fractions (active as synthase $I$, total activity $700 \mathrm{nmol} / \mathrm{ml}$ per h) were assayed for GST activity with $1 \mathrm{mM}$ 1-chloro-2,4-dinitrobenzene as substrate, and this activity cochromatographed with the synthase I activity. Using this chromophoric substrate, the pooled fractions had a total activity of $40 \mathrm{~mol} / \mathrm{min}$ per mol enzyme (data not shown). These fractions were concentrated by ammonium sulfate ( $70 \%$ saturation) and dialyzed against $1 \mathrm{mM}$ BME, $10 \mathrm{mM}$ Tris, and $50 \mathrm{mM}$ sodium phosphate, $\mathrm{pH}$ 7.0. The enzyme was applied to a Sephadex G-100 and eluted with $1 \mathrm{mM}$ BME, $10 \mathrm{mM}$ Tris, and $50 \mathrm{mM}$ sodium phosphate, $\mathrm{pH} 7.0$ (Fig. 5). A single peak of synthase activity (total pool activity, $434 \mathrm{nmol} / \mathrm{ml}$ per h) was observed in $62 \%$ yield and a single peak of GST activity co-chromatographed (total pool activity, $24 \mathrm{~mol} / \mathrm{min}$ per mol enzyme) in $60 \%$ yield. Finally, the pool from the Sephadex G-100 column was dialyzed against phosphate-buffered saline, pH 7.4 and

Table II. Amino Acid Composition of Human Heart Synthase I, Human Heart Major Synthase, and Rabbit Heart Major FAEE Synthase

\begin{tabular}{lccc}
\hline & $\begin{array}{c}\text { Human heart* } \\
\text { synthase I } \\
(26,000 \text { mol wt })\end{array}$ & $\begin{array}{c}\text { Human heart } \\
\text { major synthase } \\
(26,000 \text { mol wt })\end{array}$ & $\begin{array}{c}\text { Rabbit heart } \\
\text { major synthase } \\
(26,000 \text { mol wt })\end{array}$ \\
\hline Asx & 29 & 23 & 23 \\
Thr & 13 & 11 & 10 \\
Ser & 18 & 17 & 17 \\
Glx & 29 & 31 & 32 \\
Pro & 11 & 10 & 10 \\
Gly & 19 & 22 & 22 \\
Ala & 20 & 20 & 20 \\
Cys & 5 & 4 & 22 \\
Val & 17 & 17 & 18 \\
Met & 5 & 5 & 6 \\
Ile & 10 & 9 & 8 \\
Leu & 20 & 20 & 16 \\
Tyr & 4 & 5 & 5 \\
Phe & 9 & 8 & 6 \\
His & 6 & 5 & 10 \\
Lys & 16 & 14 & 13 \\
Arg & 12 & 10 & 7 \\
& & & \\
\hline
\end{tabular}

\footnotetext{
* This study.
}

‡ Bora et al. (4) and Mogelson and Lange (9). 
Table III. Kinetic Constants* for FAEE Synthase I

\begin{tabular}{lcc}
\hline \multicolumn{1}{c}{ Fatty acid } & $K_{\mathrm{m}}$ & $V_{\max }$ \\
& $m M$ & $n m o l / m g$ per $h$ \\
Oleic & 0.44 & 200 \\
Linoleic & 0.59 & 222 \\
Arachidonic & 0.52 & 80 \\
Palmitic & 0.57 & 32 \\
Stearic & 0.40 & 36
\end{tabular}

* Determined at $0.2 \mathrm{M}$ ethanol, $200 \mathrm{mM}$ phosphate, $\mathrm{pH}$ 7.2.

was applied to S-hexylglutathione agarose (16), previously equilibrated with phosphate-buffered saline, $\mathrm{pH}$ 7.4. After applying the sample, the column was washed with this buffer until the effluent was free of protein. The enzyme was eluted by raising the $\mathrm{pH}$ to $9.6\left(4^{\circ} \mathrm{C}\right)$ with $0.05 \mathrm{M}$ Tris buffer containing $5 \mathrm{mM}$ GSH. These fractions were active for both synthase I (total activity $118 \mathrm{nmol} / \mathrm{ml}$ per $\mathrm{h}$, yield $17 \%$ ) and GST ( $8 \mathrm{~mol} / \mathrm{min}$ per mol enzyme) with $20 \%$ yield. SDS-PAGE of this material showed a single band at $26 \mathrm{kD}$, further indicating that synthase I may be one of the members of GSTs.

\section{Discussion}

FAEEs are nonoxidative products of ethanol metabolism, and accumulate in heart and in other organs that are damaged by alcohol abuse $(5,8,16)$. For example, FAEE synthesis was observed in homogenates of human pancreas and liver at 468 and $137 \mathrm{nmol} / \mathrm{mg}$ per $\mathrm{h}$, respectively (17) and the enzymes catalyzing this reaction have been partially purified (data not shown). We have purified to homogeneity from rabbit and human myocardium both the minor and major forms of synthase, which elute from DEAE cellulose at $\mathrm{pH} 8.0$ at conductivities of 7 and $11 \mathrm{mS}$, respectively $(4,9)$. However, in human myocardium, a satellite peak previously unrecognized in rabbit heart was observed eluting at $5 \mathrm{mS}$ and designated synthase I. In the present investigation, we have extended our work to

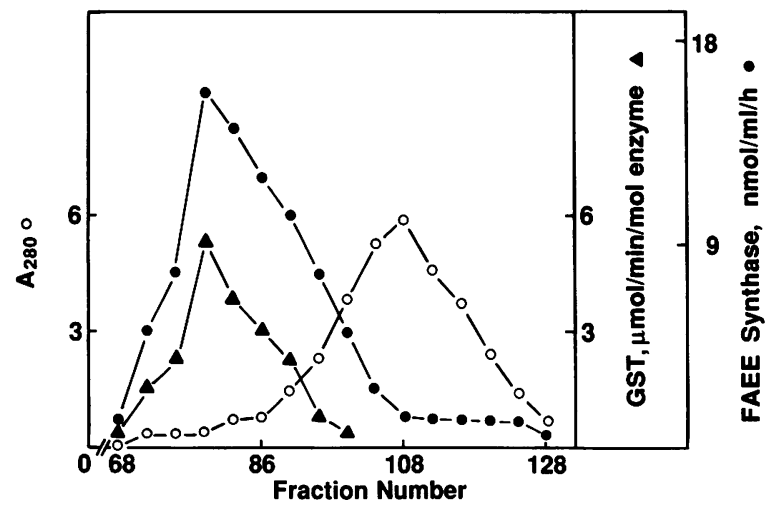

Figure 5. Co-chromatography of synthase I and GST activity. Synthase I activity from DEAE-cellulose chromatography was pooled, concentrated by ammonium sulfate precipitation, and then applied at $6 \mathrm{ml} / \mathrm{h}$ to Sephadex G-100 $(2.5 \times 72 \mathrm{~cm})$, equilibrated with $1 \mathrm{mM}$ BME, $10 \mathrm{mM}$ Tris, and $50 \mathrm{mM}$ sodium phosphate, $\mathrm{pH}$ 7.0. Fractions $(2.5 \mathrm{ml})$ were collected and monitored for $A_{280}(\mathrm{O})$, FAEE synthase activity $(\bullet)$ and GSH transferase activity $(\bullet)$, as described in Methods. purify synthase I to homogeneity from the human myocardium, and we show it to be a member of the GSTs. Our results thus establish a link between alcohol and xenobiotic/carcinogen metabolism (4).

A detailed kinetic study of synthase I demonstrated a marked substrate specificity. Highest rates of ethyl ester synthesis were found with linoleic and oleic acids, the same pattern as that found with human major synthase, but the synthase I is twofold more active than the major synthase. Thus, $V_{\max }$ for the synthesis of ethyl oleate by human synthase $I$ is $200 \mathrm{nmol} / \mathrm{mg}$ per $\mathrm{h}$, whereas that for the major synthase is 100 $\mathrm{nmol} / \mathrm{mg}$ per $\mathrm{h}$. The $K_{\mathrm{m}}$ value of synthase I for all fatty acids is $0.40-0.59 \mathrm{mM}$, whereas the $K_{\mathrm{m}}$ value of the major synthase for all fatty acids is $0.10-0.20 \mathrm{mM}$, slightly lower than those found for synthase I.

Synthase $\mathrm{I}$ is a dimer with a molecular mass of $52 \mathrm{kD}$. SDS-PAGE shows that the subunit molecular mass of Synthase $I$ is $26 \mathrm{kD}$, similar to that of the major synthase (4). Synthase I cross-reacts with the antibody raised against homogeneous human heart major synthase, both in radioimmunoassay and immunoblotting analyses. Immunoblots of synthase I show a band at $26 \mathrm{kD}$ which indicates that synthase I has a subunit molecular mass of $26 \mathrm{kD}$, and also that synthase I and the major synthase may share an epitope. Antibody does not cross-react with the minor synthase $(65 \mathrm{kD})$ by radioimmunoassay, suggesting that synthase I and the major synthase may differ from the minor synthase. These immunologic and structural data, together with activity measurements using 1chloro-2,4-dinitrobenzene as a substrate, indicate that synthase I is a member of the GST family.

Recently, we have shown that the major synthase has sequence and functional homology to GSH transferases (4). The GSH transferases comprise a family of isoenzymes that are capable of detoxifying a variety of xenobiotics through the conjugation of reduced GSH to electrophilic centers in such molecules (18). Rat heart contains several acidic and neutral GSTs with isoelectric points of $4.9,5.2,5.5$, and 6.8 , but they have not been purified to homogeneity from the heart of any species (19). Since the major synthase has a pI of 4.9 , it is an acidic GST. Since synthase $I$ is structurally and functionally similar to the major synthase, it may be that synthase I is also one of the acidic or neutral GSTs. Our co-chromatography experiments have shown that synthase I and GST activities are eluted together. Presently, it is not known why synthase I contains low levels of GST activity when compared to those found in human heart or other tissues $(4,18,20)$. However, it has been reported that GST activity may be lost either because of structural modifications or because of the presence of inhibitory factors $(21,22)$.

Inclusion of an alcohol-metabolizing enzyme within the group comprising the GSH S-transferases bears importantly on the long-appreciated relationship between alcohol abuse and the propensity to develop tumors of the pharynx, esophagus, stomach, and liver $(23,24)$. These organs are exposed to high concentrations of ethanol (100-500 mM), where excessive FAEE generation may occur. Because GSTs are the major route for elimination of endogenous and ingested carcinogens, co-metabolism of ethanol and carcinogens by these enzymes may affect end-product concentrations and biological halflives of either or both. Thus, environmental influences on the rates of ethanol metabolism and xenobiotic transformation may be interrelated since numerous agents, such as ethanol, 
phenobarbital and thyroid hormone, may induce the GSH transferases.

\section{Acknowledgments}

This article is dedicated to the memory of Heera Bora.

We thank David Scherrer for help in raising the antibody and Helen Nikolaisen for assistance with the manuscript.

This work was supported in part by National Institutes of Health/ NIAAA grants R01-AA07656 and R01-AA06989 and a grant from the Alcoholic Beverage Medical Research Foundation.

\section{References}

1. World Health Organization. 1964. Association between drinking and carcinogenesis. World Health. Bull. 9:16-17.

2. Capal, I. D., M. Turner, M. M. Pinnocle, and D. C. Williams. 1978. The effect of chronic alcohol intake upon the hepatic microsomal carcinogen-activation system. Oncology (Basel). 35:168-174.

3. McCoy, G. D., S. S. Hecht, S. Katayama, and E. L. Wynder. 1981. Differential effect of chronic ethanol consumption on the carcinogenicity of $N$-nitrosopyrolidine and $N^{\prime}$-nitrosonornicotine in may Syrian golden hamsters. Cancer Res. 61:2849-2854.

4. Bora, P. S., C. A. Spilburg, and L. G. Lange. 1989. Metabolism of ethanol and carcinogens by glutathione transferases. Proc. Natl. Acad. Sci. USA. 86:4470-4473.

5. Lange, L. G., and B. E. Sobel. 1983. Myocardial metabolism of ethanol. Circ. Res. 52:479-482.

6. Lange, L. G., S. R. Bergmann, and B. E. Sobel. 1981. Identification of fatty acid and ethyl esters as products of rabbit myocardial ethanol metabolism. J. Biol. Chem. 256:12968-12973.

7. Lange, L. G. 1982. Nonoxidative ethanol metabolism: formation of fatty acid ethyl esters by cholesterol esterase. Proc. Natl. Acad. Sci. USA. 79:3954-3957.

8. Hungund, B. L., D. B. Goldstein, F. Villegas, and T. B. Cooper. 1988. Formation of fatty acid ethyl esters during chronic ethanol treatment in mice. Biochem. Pharmacol. 37:3001-3004.

9. Mogelson, S., and L. G. Lange. 1984. Nonoxidative ethanol metabolism in rabbit myocardium: purification to homogeneity of fatty acid acyl ethyl ester synthase. Biochemistry. 23:4075-4081.

10. Bradford, M. M. 1976. A rapid and sensitive method for the quantitation of microgram quantities of protein utilizing the principle of protein-dye binding. Anal. Biochem. 72:248-254.

11. Habig, M., J. Pabst, and W. B. Jakoby. 1974. Glutathione S-transferases: the first enzymatic step in mercapturic acid formation. J. Biol. Chem. 249:7130-7139.

12. Laemmli, U. K. 1970. Cleavage of structural proteins during the assembly of the head of bacteriophage T4. Nature (Lond.). 227:680-685.

13. Merrill, C. R., D. Goldman, S. A. Sedman, and M. N. Ebart. 1981. Ultrasensitive stain for proteins in polyacrylamide gel shows regional variation in cerebrospinal fluid proteins. Science (Wash. DC). 211:1937-1938.

14. Towbin, H., T. Stachelin, and J. Gordon. 1979. Electrophoretic transfer of proteins from polyacrylamide gels to nitrocellulose sheets: procedure and some applications. Proc. Natl. Acad. Sci. USA. 76:4350-4354.

15. Gershoni, J. M., F. E. Davis, and G. E. Palade. 1985. Protein blotting in uniform or gradient electric fields. Anal. Biochem. 144:3240.

16. Vander Jagt, D. L., L. A. Hunsaker, K. B. Garcia, and R. E. Royer. 1985. Isolation and characterization of multiple glutathione S-transferases from human liver: evidence for unique heme binding sites. J. Biol. Chem. 260:11603-11610.

17. Laposata, E. A., and L. G. Lange. 1986. Presence of nonoxidative ethanol metabolism in human organs commonly damaged by ethanol abuse. Science (Wash. DC). 231:497-499.

18. Mannervik, B. 1985. The isoenzymes of glutathione transferase. Adv. Enzymol. 57:357-417.

19. Toshihisa, I., and S. Helmut. 1984. The isozyme pattern of glutathione transferases in rat heart. FEBS (Fed. Eur. Biochem. Soc.) Lett. 169:156-160.

20. Jakoby, W. B. 1978. The glutathione S-transferases: a group of multifunctional detoxification proteins. Adv. Enzymol. 46:383-421.

21. Wistow, G., and J. Piatigorsky. 1987. Recruitment of enzymes as lens structural proteins. Science (Wash. DC). 236:1554-1556:

22. Tomarev, S., and R. D. Zinovieva. 1988. Squid major lens polypeptides are homologous to glutathione S-transferases subunits. Nature (Lond.). 336:86-88.

23. Lieber, C. S., H. K. Seitz, and A. J. Gaoro. 1979. Alcohol-related diseases and carcinogenesis. Cancer Res. 39:2863-2867.

24. Engstrom, J. E. 1977. Colorectal cancer and beer drinking. Br. J. Cancer Res. 35:679-684. 